\title{
Periods of weed plant interference in canola
}

\author{
Daiani Brandler ${ }^{1 *}$, Leandro Galon ${ }^{1}$, Altemir José Mossi ${ }^{1}$, Thalita Pedrozo Pilla ${ }^{1}$, Rodrigo José Tonin ${ }^{1}$, Cesar \\ Tiago Forte $^{2}$, Felipe Bianchessi ${ }^{1}$, Emanuel Rodrigo de Oliveira Rossetto ${ }^{1}$ and Siumar Pedro Tironi ${ }^{3}$
}

\author{
${ }^{1}$ Federal University of Fronteira Sul, Erechim, RS, Brazil. \\ ${ }^{2}$ Federal University of Santa Maria, Santa Maria, RS, Brazil. \\ ${ }^{3}$ Federal University of Fronteira Sul, Chapecó, SC, Brazil. \\ Correspondence to: daianibrandler@hotmail.com
}

\begin{abstract}
OPEN ACCESS
(C) The Author

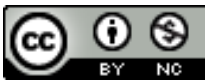

Submitted on June 22, 2020

Accepted on April 09, 2021

Early View on April 12, 2021 Final Publication on April 13, 2021

Author declares no conflict of interest

KEYWORDS:

Brassica napus var. oleifera Lolium multiflorum

Raphanus sp. Avena strigosa

\section{ABSTRACT}

The objective of this work was to determine the periods of interference of turnip, ryegrass and black oats infesting the canola crop. Two models of interference were studied: first, the canola cohabited with weeds for increasing periods up until $0,7,14,21,28,35$ and 42 days after the emergency (DAE) and throughout the cycle; second, the culture was kept free of the infestation for the same periods described previously. At $51 \mathrm{DAE}$, the variables related to canola and weed morphophysiology were determined. In the harvest of the crop, was measured the number of siliques, a thousand grain mass and grain yield. The physiological variables, photosynthetic rate, internal $\mathrm{CO}_{2}$ concentration, perspiration rate, stomach conductance of water vapors, carboxylation efficiency and efficient water use did not show significant variation. The dry mass was reduced by $79.21 \%$ when canola culture was always in competition with ryegrass, turnip and black oat weeds. The number of siliques and the mass of one thousand grains also decreased as the period of competition with the turnip, ryegrass and black oat weeds increased. The period before the interference (PAl) of the weeds ryegrass, turnip and black oats goes up to $25 \mathrm{DAE}$ of canola. The critical interference prevention period $(\mathrm{PCPI})$ for canola culture goes from 25 to $60 \mathrm{DAE}$. And the total interference prevention period (PTPI) is 60 DAE. Interference from weeds has reduced by $94.05 \%$ the productivity of canola grains when it has not received control of ryegrass, turnip and black oats.
\end{abstract}

\section{Highlighted Conclusion}

Weeds have to be controlled from 25 to 60 days after emergence to prevent canola yield reduction by up to $94 \%$.

\section{INTRODUCTION}

Canola (Brassica napus L. oleifera variety) is one of the most produced oil plants in the world (Kirkegaard et al. 2018). This crop has a great potential for grain production in Brazil, as it is an economic alternative for producers, since it can be used for crop rotation or even for the production of vegetable oils (Angus et al. 2015). The amount of canola produced in Brazil in the 2017/18 crop season was 49.5 thousand tons (Conab 2019), and the southern states contributed with the most pf the harvest.

Canola oil can be used for human consumption due to its properties, being classified as a functional food and can also be used for the production of biodiesel (Grassano et al. 2011). In Brazil, only spring canola, obtained through genetic improvement of Colza, that has low levels of erucic acid, glucosinolates and fats is grown. Erucic acid and glucosinolates are highly toxic to humans and animals when ingested in high doses as they may cause heart damage, myocardial lipidosis. In animals glucosinolate affects the palate, reduces weight gain and can cause reproduction problems (Tomm et al. 2009; Kadivar et al. 2010; Enjalbert et al. 2013).

The cultivation of canola as well as any agricultural crop is subject to competition for light, water and nutrients with other plants present in the area, which are undesirable in the crop, known as weeds (Tomm 2005; Swanton et al. Long et al. 2016; Sardana et al. 2017). Among the main winter crops, canola when compared to cereal grains, presents low competitive capacity when infested by weeds (Hashem et al. 2010). In a plant community, the competition depends on several factors, among them the crop in which the weeds, cultivars and plant populations 
are present, the ecological niche (with its specific composition, density and distribution), management are the main ones (Bachega et al. 2013).

Weeds cause losses in grain yield, reduce the quality of the harvested product, decrease the value of the land, host insects and diseases and some can still be toxic to humans and animals (Shekhawat et al. 2017). The magnitude of crop losses is determined by the duration and intensity of weed competition with the crop, and in order to avoid or reduce these losses, diversified and effective management programs are needed (Chauhan and Opeña 2013; Swanton et al. 2015).

Weed infestation can reduce crop yields when no method of management is adopted. For example, weeds in okra (Abelmoschus esculentus) can cause up to 95\% loss (Bachega et al. 2013). In canola, the highest proportion of turnip and ryegrass plants was the leaf area of the crop (Galon et al. 2015). Turnip causes losses of up to $90 \%$ in canola production when uncontrolled, due mainly to the shading that is imposed on the crop (Blackshaw et al. 2002). In addition to productivity losses when canola competes with the turnip, one can still reduce the quality of the harvested product. Different shading periods made with nylon mesh in the canola caused stress in the crop and caused it to reduce the oil content of the seeds (Kirkegaard et al. 2018).

Cultivated plants present less capacity for competition, since they underwent several improvement processes, both in their structure and in their productive potential, as a consequence of their intense use by man to meet the demands of food (Fontes et al. 2003). In general, the longer the period of coexistence of the crop with the weed community, the greater the degree of interference (Pitelli 1987; Resende and Costa 2007).

Weed and crop weed interference periods are known as: total period of interference prevention (PTPI), period prior to interference (IPA) and the critical period of interference prevention (PCPI). By conducting the study of these three periods, the best time to control weeds by infesting a particular crop can be determined (Pitelli and Durigan 1984).

PAl is the period in which weeds coexist for a certain time at the beginning of the crop cycle, without causing damage to the cultivated species. However, the PTPI corresponds to the period in which, after emergence, the crop has to develop free of weeds, so that its productivity is not significantly reduced (Kozlowzki et al. 2002). Weed species that settle after the PTPI will no longer have significant conditions to interfere with the productivity of the cultivated plant, where the crop has the capacity to suppress weeds that emerge. Between the EPI and the PTPI, there is the PCPI, in which the crop must be free of weeds so that the losses do not compromise the producer's profits (Gazziero et al. 2001).

The hypothesis of the work was that the longer canola cultivates Diamond lives with weeds, turnip, ryegrass and black oats, the greater are the physiological interferences and the losses of grain yields of the crop. In this sense, this work had the objective of determining the periods of interference of turnip, ryegrass and black oats infesting the canola crop.

\section{MATERIAL AND METHODS}

The experiments were conducted at the Federal University of Fronteira Sul (UFFS), Erechim/RS, in the agricultural year 2017/18. The soil of the experimental area is classified as Humic Aluminoferric Red Latosol, Erechim mapping unit (Streck et al. 2008), presenting clay content higher than $60 \%$. Soil fertilization was performed according to the physico-chemical analysis, followed by the technical recommendations for cultivation (SBCS 2016), using $350 \mathrm{~kg}$ ha $^{-1}$ of fertilizer formulation 05-20-20 (NPK) in the moment of sowing canola.

Each experimental unit consisted of an area of $15 \mathrm{~m}^{2}(5 \times 3 \mathrm{~m})$, being sown in a no-tillage system on 06/14/2017. For the sowing, a seeder/fertilizer with six lines, spaced $50 \mathrm{~cm}$ apart, was used. The hybrid of canola used was Diamond at the density of 50 plants $\mathrm{m}^{-2}$.

The experimental design was a randomized block design with four replicates. The treatments were separated into two models of interference: in the first, the canola cohabited with weeds for increasing periods up to $0,7,14$, $21,28,35$ and 42 days after the emergency (AED) and throughout the cycle (133 AED); being called the coexistence group and, in the second, the culture was kept free of the infestation for the same periods described previously, called control.

Weeds were removal handling with a hoe at the end of each coexistence period and/or control. At 51 AED, the height $(\mathrm{cm})$ and stem diameter $(\mathrm{mm})$ were randomly evaluated in 10 canola plants of each experimental unit, number of plants per $\mathrm{m}^{2}$. A ruler graduated in millimeters was used to evaluate plant height. The stem diameter was evaluated using a digital caliper at $5 \mathrm{~cm}$ above ground. At the same time, chlorophyll content (TC), photosynthetic rate, internal $\mathrm{CO}_{2}$ concentration, transpiration rate, stomatal conductance of water vapors, carboxylation efficiency, water efficiency, area leaf, dry mass of the aerial part of the crop and weeds. 
To evaluate the chlorophyll content (TC), a portable chlorophyllometer model SPAD 502 - Plus was used, determining the measurements in five points of each plant, in the lower, middle and upper leaves of the canopy. The photosynthetic rate $\left(\mathrm{A}-\mu \mathrm{mol} \mathrm{m} \mathrm{m}^{-2} \mathrm{~s}^{-1}\right)$, internal $\mathrm{CO}_{2}$ concentration $\left(\mathrm{Ci}-\mathrm{mol} \mathrm{mol}^{-1}\right)$, transpiration rate $(\mathrm{E}-\mathrm{mol}$ $\mathrm{H}_{2} \mathrm{O} \mathrm{m} \mathrm{m}^{-2} \mathrm{~s}^{-1}$ ), stomatal conductance of vapors $\left(\mathrm{g}-\mathrm{mol} \mathrm{m}^{-1} \mathrm{~s}^{-1}\right)$, carboxylation efficiency (EC-mol $\left.\mathrm{CO}^{2} \mathrm{~m}^{-2} \mathrm{~s}^{-1}\right)$ and water efficiency (UEA-mol $\mathrm{CO}_{2} \mathrm{~mol} \mathrm{H}_{2} \mathrm{O}^{-1}$ ) were measured in the middle third of the last completely expanded leaf of plants. Efficiency of the carboxylation $\left(\mathrm{EC}-\mathrm{mol} \mathrm{CO}_{2} \mathrm{~m}^{-2} \mathrm{~s}^{-1}\right.$ ) and water use efficiency (UEA - mol $\mathrm{CO}_{2} \mathrm{~mol}_{2} \mathrm{O}^{-1}$ ) were calculated from the $\mathrm{A} / \mathrm{Ci}$ and $\mathrm{A} / \mathrm{E}$ ratio respectively. An infrared gas analyzer (IRGA), brand ADC, model LCA PRO (Analytical Development Co. Ltd, Hoddesdon, UK) was used. Each block was evaluated under natural light in one day, between eight and ten o'clock in the morning, in clean sky conditions, so that the homogeneous environmental conditions were maintained during the analyzes.

To measure the leaf area $\left(\mathrm{cm}^{2} \mathrm{~m}^{-2}\right)$ a portable $\mathrm{Cl}-203$ BioScence leaf area meter was used, with the variable being quantified in an area of $0.25 \mathrm{~m}^{2}(0.5 \times 0.5 \mathrm{~m})$ in each parcel. After the determination of the $\mathrm{FA}$, the plants were conditioned in paper bags and placed in a drying oven in a forced air circulation at a temperature of $60 \pm 5^{\circ} \mathrm{C}$ until the material reached a constant mass to verify the dry mass of the aerial part of the species.

At the time of harvest, yield components of canola expressed as: number of siliqua per plant (counted in three plants), mass of one thousand grains and grain yield $\left(\mathrm{kg} \mathrm{ha}^{-1}\right)$ were determined. The mass of 1000 grains $(\mathrm{g})$ was determined by counting 8 samples of 100 grains each and weighing them in an analytical balance. The grain yield quantification was obtained by manual harvesting of the plants in a $3 \times 1.5 \mathrm{~m}$ area, from each experimental unit, when the grain moisture content reached approximately $18 \%$. After the grains were weighed, their moisture content was determined, the masses being corrected for $10 \%$ moisture content and the values expressed in $\mathrm{kg} \mathrm{ha}^{-1}$.

The results were submitted to analysis of variance by the F test, in which the ICP (period prior to interference), PCPI (critical period of interference prevention), and TPPI (total period of interference prevention) were determined, ryegrass and black oats on canola crops. For the determination of the interference periods, the grain yield variable $\left(\mathrm{kg} \mathrm{ha}^{-1}\right)$ of the crop was used, according to the methodology proposed by Pitelli and Durigan (1984).

For the other variables, Student's t-test was used to evaluate the effects of coexistence and control periods between weeds and culture; and linear and non-linear regressions for the periods of coexistence and control at $5 \%$ probability of error.

Productivity data, standardized to $10 \%$ dry basis moisture and expressed in $\mathrm{kg} \mathrm{ha}^{-1}$, were submitted to regression analysis using the nonlinear regression model. This model obeys the following logistic equation:

$$
Y=\frac{a}{\left[1+\left(\frac{x}{b}\right)^{c}\right]}
$$

where: $Y=$ grain yield, $x=$ number of days after emergence of canola crop; $a=$ maximum productivity obtained from the clean control; and $b=$ number of days in which $50 \%$ of the reduction in maximum productivity occurs; and $\mathrm{c}=$ slope of the curve. Based on the regression equations, the weed interference periods were determined on canola, subtracting $5 \%$ of the maximum estimated productivity in the regression equations in relation to the treatment maintained in the absence of infestation, considered as cost of adopting control.

\section{RESULTS AND DISCUSSION}

The physiological variables, photosynthetic rate, internal $\mathrm{CO}_{2}$ concentration, perspiration rate, stomach conductance of water vapors, carboxylation efficiency and efficient use of water didn't show significant variation, there was only small variation between treatments, what differed was only the periods where the crop was kept free and/or infested with weeds throughout the cycle (Figures 1, 2, 3 and 4). These results corroborate those reported by Bastiani et al. (2016), when evaluating the competitiveness of soybean cultivars with grass as they did not find significant results for the variables studied of the crop in the presence of weeds. A study carried out on wheat crops (Fang et al. 2018) and sunflower crops (Reis et al. 2014) also did not show significant results for the same variables studied.

Along the development of canola culture with the weeds its dry mass has been suffering reductions (Figure 4), and this can be explained by the direct competition for water, light and nutrients among the cultivated species. In the period in which the crop was always free of weeds its dry mass was $79.21 \%$ higher than when canola was always in competition. When comparing the control versus coexistence by 7 and 14 DAE the losses of dry mass were approximately $41 \%$. In radish the weeds caused a decrease in dry mass and this crop needs to be free of competition from the 5th DAE, after that, it is necessary to do the control to enable greater and better growth of the plants (Dos Santos et al. 2015). Ryegrass in high densities can cause drastic reduction, up to $81 \%$ of barley dry mass, both emerging before and together with the crop (Galon et al. 2011; Tironi et al. 2014). 

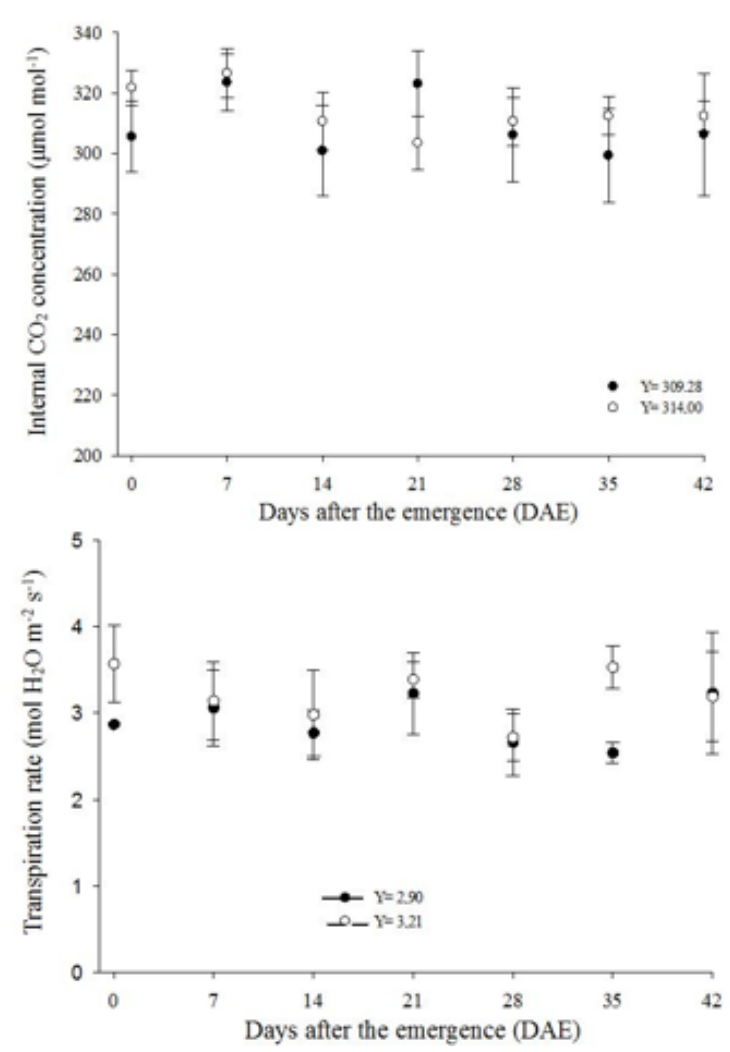

Figure 1. Effect of coexistence $(\bullet)$ or weed control periods $(\circ)$ on the internal $\mathrm{CO}_{2}$ concentration ( $\mu \mathrm{mol} \mathrm{mol}{ }^{-1}$ ) and the transpiration rate $\left(\mathrm{mol} \mathrm{H}_{2} \mathrm{O} \mathrm{m}^{-2} \mathrm{~s}^{-1}\right)$ of the canola, Diamond hybrid. UFFS, Erechim/RS, 2018.
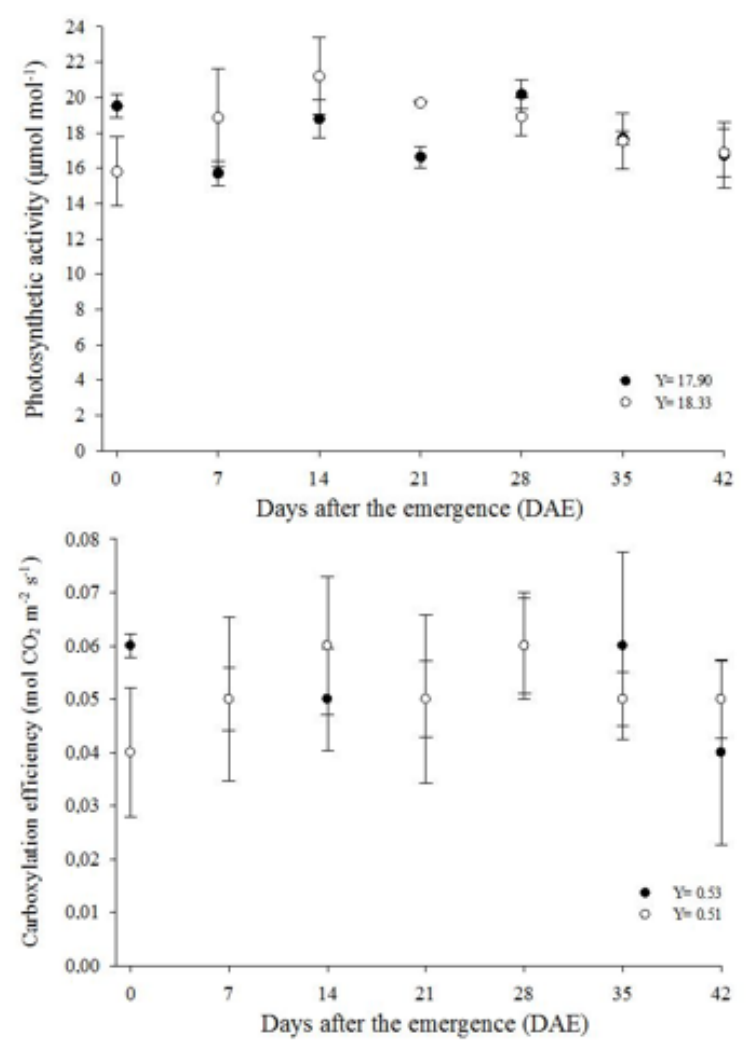

Figure 3. Effect of coexistence ( $\bullet$ ) or weed control $(\circ)$ on photosynthetic activity $\left(\mu \mathrm{mol} \mathrm{mol}{ }^{-1}\right)$ and carboxylation efficiency ( $\mathrm{mol} \mathrm{CO} \mathrm{C}^{-2} \mathrm{~s}^{-1}$ ) of canola, Diamond hybrid. UFFS, Erechim/RS, 2018.
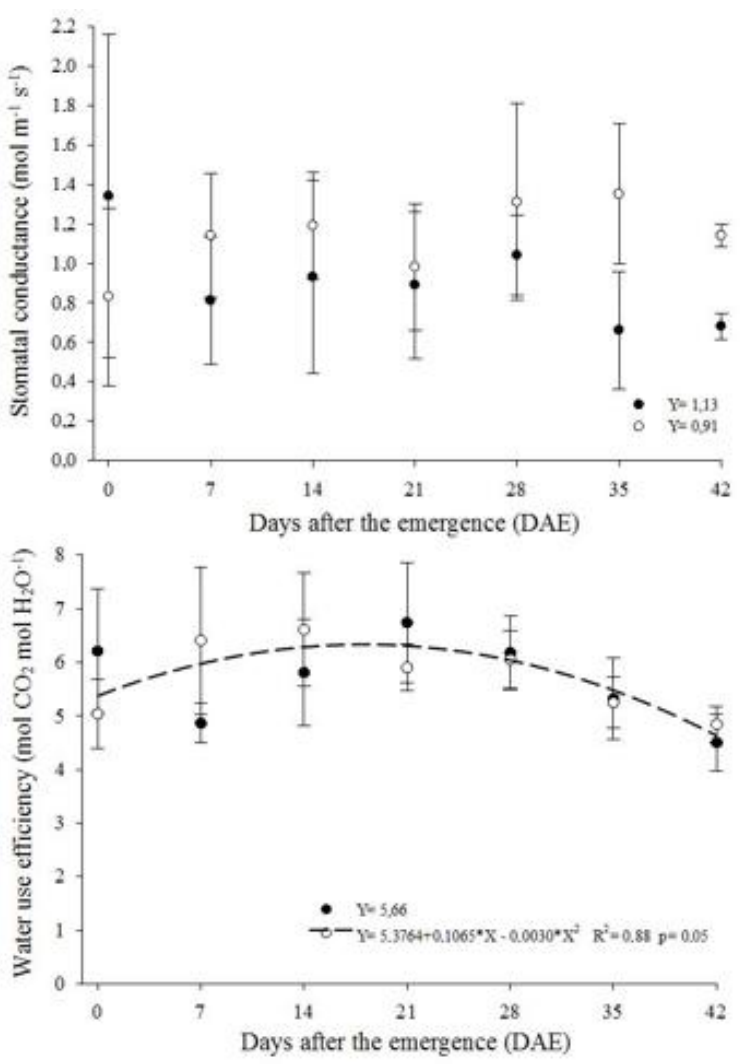

Figure 2. Effect of coexistence $(\bullet)$ or weed control $(\circ)$ on stomatal conductance $\left(\mathrm{mol} \mathrm{m}^{-1} \mathrm{~s}^{-1}\right)$ and water use efficiency ( $\mathrm{mol} \mathrm{CO}_{2} \mathrm{~mol} \mathrm{H}_{2} \mathrm{O}^{-1}$ ) Diamond hybrid. UFFS, Erechim/RS, 2018.
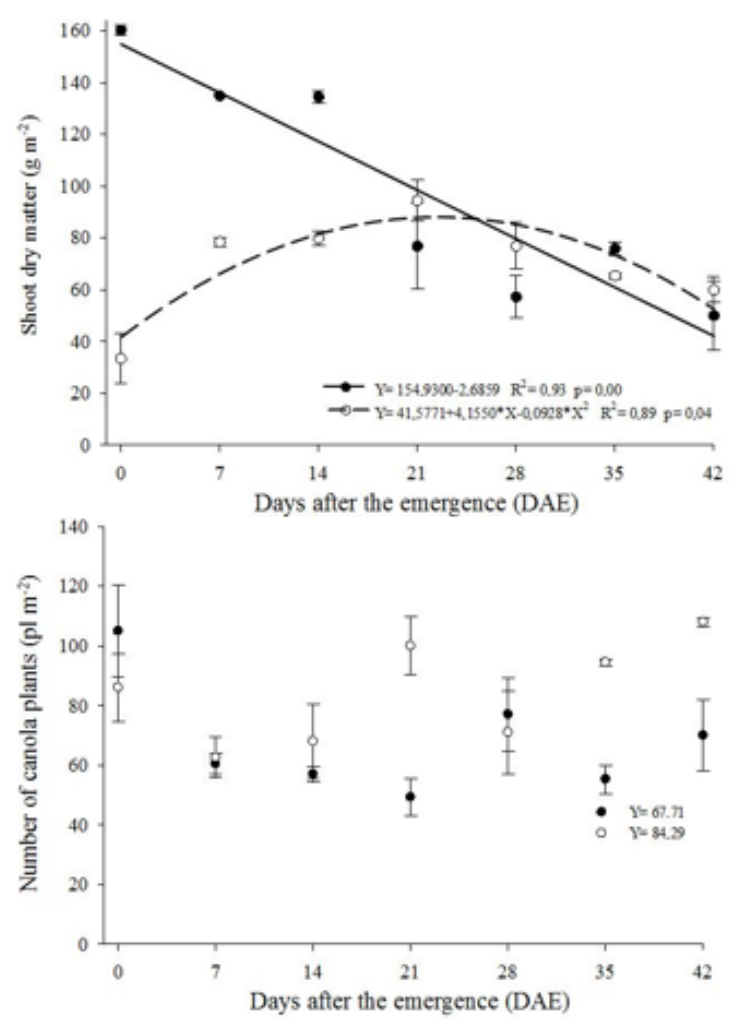

Figure 4. Effect of coexistence $(\bullet)$ or weed control $(\circ)$ periods on shoot dry matter $\left(\mathrm{g} \mathrm{m}^{-2}\right)$ and number of canola plants, Diamond hybrid. UFFS, Erechim / RS, 2018. 
A reduction of $29.46 \%$ in the height of plants and $50 \%$ in the diameter of the canola stem was observed when the crop lived with the weeds throughout the cycle (Figure 5). The height of the canola plants in the periods of 7 and 14 DAE was higher in the control treatment (Figure 5). This fact may be related to the competition that occurred for light, where the culture increased the accumulation of photoassimilates in the growth of the stem. The competition for light can make the plants invest more in the development of stems in detriment of other organs aiming to reach greater stature as a strategy to increase the capture of luminosity (Castro and Garcia 1996). Studies conducted by De Oliveira et al. (2016) and Diniz et al. (2017) on the cultivation of sorghum and studies conducted by Marques (2001) on the cultivation of crambe with 21 species of weeds and the studies of Amaral et al. (2015) presented results that corroborate with the results found where the occurrence of weeds affects the growth of canola plants, because the crop cannot intercept a sufficient amount of light to develop properly (Li et al. 2018).

Subscribe to DeepL Pro to edit this document. Visit www.DeepL.com/Pro for more information. The foliar area of the canola plants that did not coexist with the weeds, turnip, ryegrass and black oat, was $60.54 \%$ greater than where the crop coexisted all cycle with the weeds. In the period of 7 and 14 DAE the reduction in leaf area was 34.40 and $45.76 \%$ when comparing the period of coexistence with the control of the respective treatments (Figure 6). This effect was probably caused by competition for light (shading), making it difficult for the crop to absorb sufficient solar radiation, thus causing an imbalance in the photosynthetic balance, interfering with the emission of new leaves in the crop. While in the treatments 28 and 35 DAE no significant difference was observed in leaf area and plant diameter between coexistence and control. Studies conducted with turnip and ryegrass culture in competition with canola hybrids caused a decrease in the leaf area of the crop (Galon et al. 2015). Evaluating the competition of black oats with crambe, Concenço et al. (2015), found that the weed caused a reduction of $74 \%$ in the leaf area of the crop when it developed in the presence of the competitor.
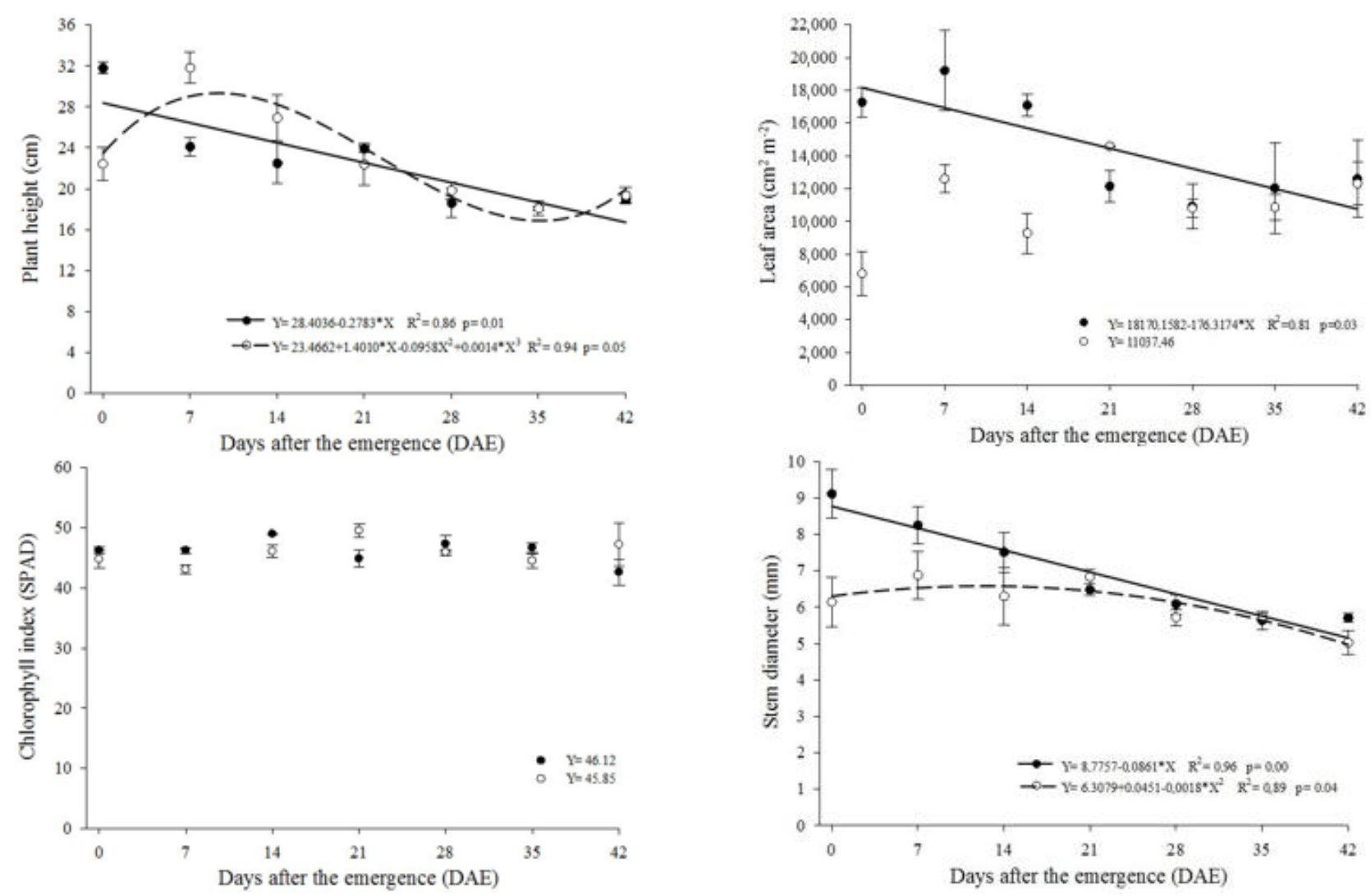

Figure 5. Effect of coexistence $(\bullet)$ or weed control $(\circ)$ on plant height $(\mathrm{cm})$ and canola chlorophyll index (SPAD), Diamond hybrid. UFFS, Erechim/RS, 2018.

Figure 6. Effect of coexistence $(\bullet)$ or weed control $(\circ)$ on leaf area $\left(\mathrm{cm}^{2} \mathrm{~m}^{-2}\right)$ and stem diameter $(\mathrm{mm})$ of canola, Diamond hybrid. UFFS, Erechim/RS, 2018.

The number of siliquas was reduced by up to $37.69 \%$ as the competition period increased (Figure 7). This may be related to the competition that caused canola plants to decrease secondary branch production as well as carbohydrate production during the flowering period. Canola in competition with wild mustard had a reduction of up to $57 \%$ in the number of siliquas (Aslani et al. 2015), results that corroborate this study. The maximum number of 
siliquas was observed in the 28-day treatment between canola and weeds (Figure 7), and this is probably the period where the crop expresses this yield component.
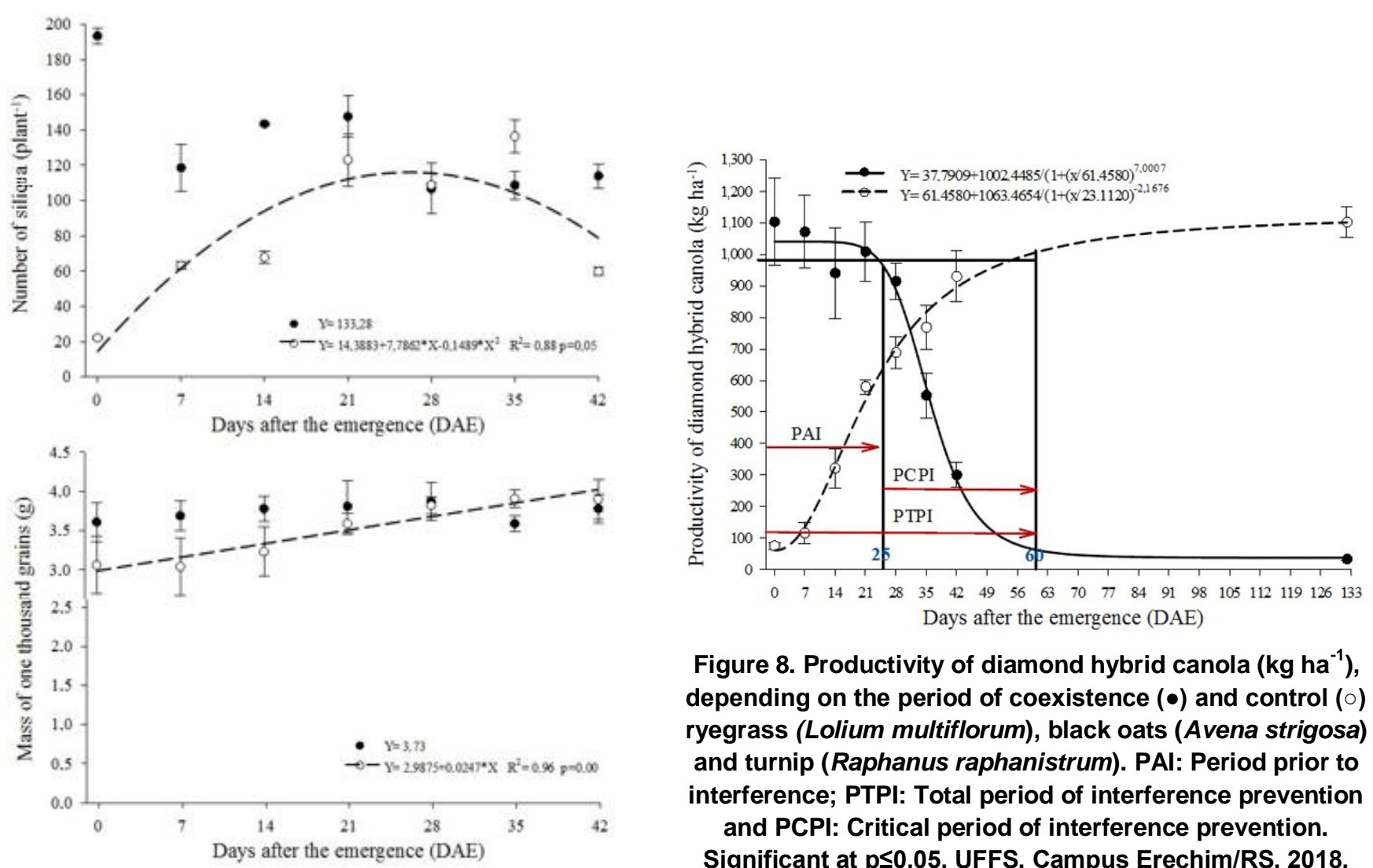

Figure 8. Productivity of diamond hybrid canola $\left(\mathrm{kg} \mathrm{ha}^{-1}\right)$, depending on the period of coexistence $(\bullet)$ and control $(0)$ ryegrass (Lolium multiflorum), black oats (Avena strigosa) and turnip (Raphanus raphanistrum). PAl: Period prior to interference; PTPI: Total period of interference prevention and PCPI: Critical period of interference prevention. Significant at $\mathrm{p} \leq 0.05$. UFFS, Campus Erechim/RS, 2018.

Figure 7. Effect of coexistence periods $(\bullet)$ or weed control $(\circ)$ on the number of siliqua (plant ${ }^{-1}$ ) and the mass of one thousand grains $(g)$ of canola, Diamond hybrid. UFFS, Erechim/RS, 2018.

The mass of one thousand grains of canola was reduced by $6.16 \%$ during the whole period, but the greatest differences were in the control periods from 0 to $14 \mathrm{DAE}$, and from $21 \mathrm{DAE}$ there was no significant difference between the control and coexistence, because from this period the control treatment had already been affected in such a way that even doing the management of weeds the crop had no more potential to produce.

The grain yield of canola was $1,009 \mathrm{~kg} \mathrm{ha}^{-1}$ where the crop always remained free of weeds and already where it was infested throughout the cycle was $60 \mathrm{~kg} \mathrm{ha}^{-1}$, showing a reduction of $94.05 \%$. This is mainly due to the great competition caused by the weeds (turnip, ryegrass and black oat) that infested and competed with the crop. Crop losses can be more severe when weeds and crops emerge simultaneously and under limited resource conditions (Fahad et al. 2015). Turnip competition (Raphanus raphanistrum) at densities of 4 and $64 \mathrm{~m}^{-2}$ plants when emerging together with canola caused yield reductions of 9 to $11 \%$ and 77 to $91 \%$, respectively (Blackshaw et al. 2002). There were grain yield reductions of canola hybrids, Okapi and Hyola 308, of 31.8 and $67.6 \%$, respectively, when competing with the weeds that emerged voluntarily (Zare et al. 2012). Lolium persicum (ryegrass) competing with canola caused $70 \%$ loss in crop yield (Holman et al. 2004).

The results show that canola culture can coexist with the weed infesting community for up to 25 days after the emergency without significant losses, where this period is called the period before the interference - PAI (Figure 8). As there was an increase in the period in which the weeds lived with the crop, the grain yield was reduced, as well as the mass of a thousand grains, the height of the plants, the diameter of the stem and leaf area and the number of siliquas per plant.

The critical interference prevention period (PCPI) ranges from 25 to $60 \mathrm{DAE}$ and the total interference prevention period (PTPI) to 60 DAE. Martin et al. (2001) observed that the PCPI for canola goes from 17 to 38 DAE of the crop, and after this period the weeds that emerge do not cause more losses in the productivity of the crop.

In conclusion, the physiological variables, photosynthetic rate, internal $\mathrm{CO}_{2}$ concentration, perspiration rate, stomach conductance of water vapors, carboxylation efficiency and efficient water use did not show significant 
variation. The dry mass was reduced by $79.21 \%$ when canola culture was always in competition with ryegrass, turnip and black oat weeds. The number of plants per square meter was not influenced by the coexistence period. The height of canola plants showed a reduction of $29.46 \%$ when the crop was in competition with the weeds. The leaf area had a reduction of $60.54 \%$ where the canola plants lived with the turnip, ryegrass and black oat weeds for the whole cycle. The diameter of the stem reduced with the increase of the period of coexistence of the crop with the weeds. The number of siliques and the mass of one thousand grains also decreased as the period of competition with the turnip, ryegrass and black oat weeds increased.

The period before the interference (PAI) of the weeds ryegrass, turnip and black oats goes up to $25 \mathrm{DAE}$ of canola. The critical interference prevention period (PCPI) for canola culture goes from 25 to $60 \mathrm{DAE}$. And the total interference prevention period (PTPI) is $60 \mathrm{DAE}$. Interference from weeds has reduced by $94.05 \%$ the productivity of canola grains when it has not received control of ryegrass, turnip and black oats.

\section{References}

Amaral CL et al. 2015. Relações de interferência entre plantas daninhas e a cultura do grão-de-bico. Bioscience Journal 31:37-46.

Angus JF et al. 2015. Break crops and rotations for wheat. Crop and Pasture Science 66:523-552.

Aslani S; Saeedipour S. 2015. Competitive interaction of canola (Brassica napus) against wild mustard (Sinapis arvensis) using replacement series method. Walia Journal 31: 111-116.

Bachega LPS et al. 2013. Períodos de interferência de plantas daninhas na cultura do quiabo. Planta Daninha 31:63-70

Bastiani MO et al. 2016. Competitividade relativa de cultivares de soja com capim-arroz. Bragantia 75:435-45.

Bianchi MA et al. 2010. Papéis do arranjo de plantas e do cultivar de soja no resultado da interferência com plantas competidoras. Planta Daninha 28:979-991.

Blackshaw RE et al. 2002. Influence of wild radish on yield and quality of canola. Weed Science 50:344-349.

Cabral PHR et al. 2013. Interferência de plantas daninhas na cultura do sorgo cultivado em safrinha. Pesquisa Agropecuária Tropical 43:308314.

Castro CRT and Garcia R. 1996. Competição entre plantas com ênfase no recurso luz. Ciência Rural 26:167-174.

Conab - Companhia Nacional de Abastecimento. Acompanhamento da safra brasileira. 2019. https://www.conab.gov.br/info-agro/safras/graos.

Concenço $\mathrm{G}$ et al. 2015. Growth of crambe under presence or absence of inter-specific competition. Revista Ceres 62:460-468.

Chavarria $\mathrm{G}$ et al. 2011. Índice de área foliar em canola cultivada sob variações de espaçamento e de densidade de semeadura. Ciência Rural 41:2084-2089.

Chauhan BS and Opeña J. 2013. Implications of plant geometry and weed control options in designing a low-seeding seed-drill for dry-seeded rice systems. Field Crops Research 144:225-231.

De Oliveira RM et al. 2016. Interferência de plantas daninhas em sorgo sacarino em diferentes espaçamentos no semiárido mineiro. Revista Brasileira de Milho e Sorgo 15:482-490.

Diniz, G. et al. 2017. Período anterior à interferência de plantas daninhas em sorgo granífero e forrageiro. Revista Brasileira de Milho e Sorgo $15: 471-481$.

Dos Santos VM et al. 2015. Análise do crescimento de rabanete em função de períodos de convivência com plantas daninhas. Revista Brasileira de Agropecuária Sustentável 5:121-129.

Enjalbert JN et al. 2013. Brassicaceae germplasm diversity for agronomic and seed quality traits under drought stress. Industrial Crops and Products 47:176-185.

Fahad S et al. 2015. Weed growth and crop yield loss in wheat as influenced by row spacing and weed emergence times. Crop Protection 71:101-108.

Fang $X$ et al. 2018. Effects of nitrogen fertilizer and planting density on the leaf photosynthetic characteristics, agronomic traits and grain yield in common buckwheat (Fagopyrum esculentum M.). Field crops research 219:160-168.

Fontes JRA and Gonçalves J. 2003. Manejo integrado de plantas daninhas. In. Manejo integrado de pragas, doenças e plantas daninhas em grãos e fruteiras: anais. 2003. Belém, PA: Embrapa Amazônia Oriental. 2003.1 CD. ROM.

Galon L et al. 2011. Habilidade competitiva de cultivares de cevada convivendo com azevém. Planta Daninha 29:771-781.

Galon L et al. 2015. Competitive ability of canola hybrids with weeds. Planta Daninha 33:413-423.

Gazziero DLP et al. 2001. As plantas daninhas e a semeadura direta. Embrapa Soja-Circular Técnica (INFOTECA-E) 33: 59 p.

Grassano N et al. 2011. Evaluation of rapeseed cultivation suitability in Apulia with GIS-multicriteria analysis. Italian Journal of Agronomy 6:16p.

Gurevitch J et al. 2009. Ecologia Vegetal-2. Artmed Editora.

Hashem A et al. 2010. Weed suppression by crop competition in three crop species in Western Australia. In 17th Australasian weeds conference. New frontiers in New Zealand: together we can beat the weeds. Christchurch, New Zealand, 26-30 September, 2010 (p. 63-66). New Zealand Plant Protection Society.

Harker KN et al. 2013. Weed interference impacts and yield recovery after four years of variable crop inputs in no-till barley and canola. Weed Technology 27:281-290.

Holman JD et al. 2004. Spring wheat, canola, and sunflower response to Persian darnel (Lolium persicum) interference. Weed Technology 18:509-520.

Kadivar S et al. 2010. Chemical evaluation of oil extracted from different varieties of colza. Journal of Food Technology and Nutrition 7:19-26.

Kirkegaard JA et al. 2018. The critical period for yield and quality determination in canola (Brassica napus L.). Field Crops Research 222:180188.

Kozlowski LA et al. 2002. Período crítico de interferência das plantas daninhas na cultura do feijoeiro-comum em sistema de semeadura direta. Planta daninha 20:213-220.

Lemos JP et al. 2012. Morfofisiologia de plantas de milho em competição com picão-preto e trapoeraba submetidas a roçada. Planta Daninha 30:487-496. 
Li X et al. 2018. Higher density planting benefits mechanical harvesting of rapeseed in the Yangtze River Basin of China. Field Crops Research 218:97-105.

Long DS et al. 2016. Development of dryland oilseed production systems in northwestern region of the USA. Bio Energy Research 9:412-429.

Marques RF. 2012. Período de interferência de plantas daninhas e seletividade a herbicidas na cultura do crambe (Crambe abyssinica Hoechst). Tese de Doutorado. Universidade Federal da Grande Dourados. 70 p.

Marques LJP et al. 2017. Interferência das plantas daninhas na cultura da berinjela. Revista Caatinga 30:866-875.

Martin SG et al. 2001. Critical period of weed control in spring canola. Weed Science 49:326-333.

Motzo $\mathrm{R}$ et al. 2013. The role of stomatal conductance for water and radiation use efficiency of durum wheat and triticale in a Mediterranean environment. European Journal of Agronomy 44:87-97.

Page ER et al. 2010. Shade avoidance: an integral component of crop-weed competition. Weed Research 50:281-288.

Pitelli RA and Durigan JC. 1984. Terminologia para períodos de controle e de convivência das plantas daninhas em culturas anuais e bianuais. In: Congresso Brasileiro de Herbicidas e Plantas Daninhas 15: 37p.

Pitelli RA. 1987. Competição e controle das plantas daninhas em áreas agrícolas. Série Técnica IPEF 4:1-24.

Reis RM et al. 2014. Physiological aspects and growth of sunflower after application of pre-emergent herbicides. Agro@ mbiente On-line 8:352358.

Resende GM and Costa ND. 2007. Plantas Daninhas. In: Costa ND; Resende GM (Ed.). Cultivo da cebola no Nordeste. Embrapa Semi-Árido, Sistemas de Produção, 90p.

Santos EF et al. 2017. Physiological highlights of manganese toxicity symptoms in soybean plants: Mn toxicity responses. Plant physiology and biochemistry 113:6-19.

Safdar ME et al. 2016. Critical competition period of parthenium weed (Parthenium hysterophorus L.) in maize. Crop Protection 80:101-107.

Sardana $\mathrm{V}$ et al. 2017. Role of competition in managing weeds: An introduction to the special issue. Crop Protection 95:1-7.

Silva $C$ et al. 2014. Interferência de plantas daninhas na cultura do sorgo sacarino. Bragantia 73:438-445.

SBCS - Sociedade Brasileira de Ciência do Solo - Núcleo Regional Sul/Comissão de Química e Fertilidade do Solo-RS/SC. 2016. Manual de adubação e calagem para os estados do Rio Grande do Sul e Santa Catarina. 11 â.ed. Porto Alegre: Sociedade Brasileira de Ciência do Solo, 376p.

Swanton CJ et al. 2015. Experimental methods for crop-weed competition studies. Weed Science 63:2-11.

Shekhawat $\mathrm{K}$ et al. 2017. Weed menace and management strategies for enhancing oilseed brassicas production in the Indian sub-continent: a review. Crop protection 96:245-257.

Streck EV et al. 2008. Solos do Rio Grande do Sul. Porto Alegre: UFRGS: EMATER/RS-ASCAR, 222 p.

Seixeira MFF et al. 2017. Interferência de plantas daninhas na qualidade e produtividade do grão-de-bico. Revista de Agricultura Neotropical 4:69-75.

Tironi SP et al. 2014. Época de emergência de azevém e nabo sobre a habilidade competitiva da cultura da cevada. Ciência Rural 44:15271533.

Tomm GO. 2005. Situação em 2005 e perspectivas da cultura de canola no Brasil e em países vizinhos. Embrapa Trigo. Boletim de Pesquisa e Desenvolvimento Online, $21 \mathrm{p}$.

Tomm GO et al. 2009. Panorama atual e indicações para aumento de eficiência da produção de canola no Brasil. Embrapa Trigo, 27p.

Thiel $\mathrm{CH}$ et al. 2018. Physiology of weeds in intraspecific competition. Journal of Agricultural Science 10:334-340.

Zare M et al. 2012. Competition of rapeseed (Brassica napus L.) cultivars with weeds. African Journal of Biotechnology 11:1378-1385.

Zuo Q et al. 2017. The effect of sowing depth and soil compaction on the growth and yield of rapeseed in rice straw returning field. Field $\mathrm{C}$ rops Research 203:47-54. 